\title{
Interaction of Heparin with Two Synthetic Peptides That Neutralize the Anticoagulant Activity of Heparin+
}

\author{
Jing Wang $\ddagger$ and Dallas L. Rabenstein * \\ Department of Chemistry, University of California, Riverside, California 92521
}

\section{Abstract}

Two synthetic analogs of the heparin-binding domain of heparin/heparan sulfate-interacting protein: Ac-SRGKAKVKAKVKDQTK-NH ${ }_{2}$ and the all-D-amino acid version of the same peptide (LHIPAP and D-HIPAP, respectively) were synthesized and their efficacy as agents for neutralization of the anticoagulant activity of heparin was assayed. The two analog peptides were found to be equally effective for neutralization of the anticoagulant activity of heparin, as measured by restoration of the activity of serine protease Factor Xa by the Coatest Heparin Method. The finding that L-HIPAP and D-HIPAP are equally effective suggests that D-amino acid peptides show promise as proteolytically stable therapeutic agents for neutralization of the anticoagulant activity of heparin. The interaction of L-HIPAP and D-HIPAP with heparin was characterized by ${ }^{1} \mathrm{H}$ NMR, isothermal titration calorimetry (ITC) and heparin affinity chromatography. The two peptides were found to interact identically with heparin. Analysis of the dependence of heparin-peptide binding constants on $\mathrm{Na}^{+}$ concentration by counterion condensation theory indicates that, on average, $2.35 \mathrm{Na}^{+}$ions are displaced from heparin per peptide molecule bound and one peptide molecule binds per hexasaccharide segment of heparin. The analysis also indicates that both ionic and nonionic interactions contribute to the binding constant, with the ionic contribution decreasing as the $\mathrm{Na}^{+}$ concentration increases.

\begin{abstract}
Heparin, a linear polysaccharide comprised of highly sulfated $1 \rightarrow 4$ linked uronic acid-(1 $\rightarrow 4)$ D-glucosamine repeating disaccharide units, has been used clinically as an anticoagulant for more than half a century $(1,2)$. Other biological activities include release of lipoprotein lipase and hepatic lipase $(3,4)$, regulation of complement activation (5), regulation of angiogenesis and tumor growth (6-8), regulation of Burkitt's lymphoma growth (9), modulation of inflammation (10) and antiviral activity (11-15). The biological activity of heparin results from its interaction with proteins, and hundreds of proteins have been shown to interact with heparin (2,16-18).

Heparin functions as an anticoagulant by binding to antithrombin III $\left(\mathrm{AT}^{1}\right)$, a serine protease inhibitor that mediates the coagulation cascade; binding causes a conformational change that accelerates inhibition of serine protease factor Xa by AT (19). In some clinical situations, for example where extracorporeal blood circulation is necessary or when patients experience moderate to severe bleeding, the anticoagulant activity must be neutralized to reduce the risk of hemorrhagic hazard. Protamine, a complex mixture of arginine-rich peptides, is used for this purpose. However, protamine can induce life-threatening side effects, such as hypotension
\end{abstract}

\footnotetext{
${ }^{+}$This work was supported in part by National Institutes of Health Grant HL56588. Funding for the Varian Inova 500 spectrometer was provided in part by NSF-ARI Grant 9601831.

\$Present address: Momenta Pharmaceuticals, Boston MA.

*To whom correspondence should be addressed. Telephone: 951-827-3585, Fax: 951-827-2435, E-mail: dlrab@ucrac1.ucr.edu.
} 
and anaphylactoid-like symptoms, including bradycardia, dyspnea, and flushing (20-24). Thus, there is interest in developing alternatives to protamine.

Carson and co-workers have shown that a cell surface heparin/heparan sulfate-interacting protein (HIP) found in a variety of human epithelial and endothelial cells binds to heparin (25). The heparin-binding domain was found to have the sequence CRPKAKAKAKAKDQTK (26). A synthetic peptide of the same sequence (HIP peptide) competes with AT for heparin and neutralizes the anticoagulant activity of heparin in blood plasma assays (26), which suggests that HIP peptide or peptides with similar sequences may have potential as clinical agents for neutralization of the anticoagulant activity of heparin (25-28).

In this paper, we report on the interaction of heparin with two synthetic analogs of HIP peptide: Ac-SRGKAKVKAKVKDQTK- $\mathrm{NH}_{2}$ and the same peptide synthesized with all D-amino acids, L-HIP analog peptide (L-HIPAP) and D-HIPAP, respectively. As compared to HIP peptide, the $\mathrm{N}$-terminus has been acetylated and the $\mathrm{C}$-terminus amidated to eliminate end group effects, the cysteine residue has been substituted by serine to eliminate dimerization by disulfide bond formation, the proline has been substituted by glycine to eliminate cis/trans isomerism across the arginine-proline peptide bond, and two alanine residues have been replaced by valine to facilitate characterization of the interaction of the peptides with heparin by NMR. Because polypeptides are rapidly degraded by proteases in vivo, and thus are generally poor drugs, both the all L-amino acid and all $\mathrm{D}$-amino acid peptides were studied. Both L-HIPAP and D-HIPAP were found to be effective agents, and to be equally effective, for neutralization of the anticoagulant activity of heparin, as determined by the Coatest Heparin method (26). Interaction of both peptides with heparin was studied by ${ }^{1} \mathrm{H}$ NMR and heparin affinity chromatography, and heparin-peptide binding constants were determined by isothermal titration calorimetry.

\footnotetext{
${ }^{1}$ Abbreviations

AT

antithrombin III

HIP

heparin/heparan sulfate-interacting protein

HIP peptide

CRPKAKAKAKAKDQTK

L-HIPAP and D-HIPAP

Ac-SRGKAKVKAKVKDQTK- $\mathrm{NH}_{2}$ synthesized from all $\mathrm{L}$ and all $\mathrm{D}$ amino acids, respectively

Hep

heparin

FXa

Factor Xa

TOCSY

TOtal Correlation SpectroscopY

ROESY

Rotating frame Overhauser Effect SpectroscopY

NOESY

Nuclear Overhauser Effect SpectroscopY

BASHD-TOCSY

BAnd-Selective Homonuclear-Decoupled TOCSY

ITC

isothermal titration calorimetry
}

Biochemistry. Author manuscript; available in PMC 2008 September 2. 


\section{MATERIALS AND METHODS}

\section{Chemicals}

L-HIPAP and D-HIPAP were synthesized as described below. Porcine intestinal mucosal heparin (sodium salt) was obtained from Sigma Chemical Co., $\mathrm{D}_{2} \mathrm{O}(99.8 \%)$ from Isotec and sodium 3-(trimethylsilyl)-propionate-2,2,3,3- $d_{4}$ (TMSP) from Cambridge Isotope Labs. All other chemicals were reagent grade. The Coatest Heparin assay kit was obtained from DiaPharma.

Anticoagulation Assays were performed using the Coatest Heparin method for determination of heparin in blood plasma. The Coatest Method is based on the following reactions:

$$
\begin{gathered}
\text { Hep }+\mathrm{AT}_{(\text {excess })} \leftrightarrow[\mathrm{AT}-\mathrm{Hep}]+\mathrm{AT}_{\text {(free) }} \\
{[\mathrm{AT}-\mathrm{Hep}]+\mathrm{FXa}_{(\text {excess })} \leftrightarrow[\mathrm{AT}-\mathrm{Hep}-\mathrm{FXa}]+\mathrm{FXa}_{\text {(free) }}} \\
\mathrm{S}-2222 \stackrel{\mathrm{FXa}_{\text {(free) }}}{\longrightarrow} \text { peptide }+\mathrm{pNA}(\text { yellow })
\end{gathered}
$$

where FXa represents Factor Xa and S-2222 represents Bz-IIe-Glu- $(\gamma-\mathrm{OR})-\mathrm{Gly}-\mathrm{Arg}-\mathrm{pNA}$, a chromogenic substrate cleaved by free FXa to peptide (Bz-IIe-Glu- $(\gamma-\mathrm{OR})-\mathrm{Gly}-\mathrm{Arg})$ and pNA (p-nitroaniline). Heparin binds to AT, causing a change in the conformation of AT to a form that binds to and sequesters the activity of FXa. Addition of a peptide that competes with AT for heparin will increase the concentration of free FXa. Thus, restoration of the activity of FXa, as indicated by the amount of S-2222 converted to peptide and pNA, provides a measure of the ability of a peptide to neutralize the anticoagulant activity of heparin (26).

The assay method was calibrated using standard solutions that contained $0.1 \mathrm{IU} / \mathrm{mL}$ of AT and heparin at concentrations ranging from 0.01 to $0.07 \mathrm{IU} / \mathrm{mL}$ in buffer/normal human plasma supplied with the Coatest kit. The standard solutions were incubated at $37^{\circ} \mathrm{C}$ for $3-4$ min, after which $100 \mu \mathrm{L}$ of bovine Factor Xa (0.71 nkat) were added to $200 \mu \mathrm{L}$ of each standard solution. The mixtures were incubated at $37^{\circ} \mathrm{C}$ for $30 \mathrm{sec}$, after which $200 \mu \mathrm{L}$ of S-2222 $\left(0.2 \mu \mathrm{mol}, 37^{\circ}\right.$ C) were added and the reaction mixtures were incubated at $37^{\circ} \mathrm{C}$ for exactly $3 \mathrm{~min}$. Reaction was stopped by addition of $300 \mu \mathrm{L}$ of $20 \%$ ( vol/vol) acetic acid. The absorbance was measured at $405 \mathrm{~nm}$ to quantitate the formation of pNA. The ability of L-HIPAP and D-HIPAP to neutralize the anticoagulant activity of heparin was determined by addition of a range of concentrations of each peptide to the $0.07 \mathrm{IU} / \mathrm{ml}$ standard heparin solution, and the assay performed as described above. Triplicate experiments were performed in the absence of peptide and at each peptide concentration.

\section{Peptide Synthesis}

L-HIPAP and D-HIPAP were synthesized on a Millipore Model 9050 plus solid phase peptide synthesizer using Fmoc peptide synthesis methodology (29). Fmoc-PAL-PEG-PS resin with a loading capacity of $0.20 \mathrm{mmol} / \mathrm{g}$ was conditioned by immersion in N,N-dimethylformamide (Fisher Scientific) for an hour. Side-chain protected Fmoc-amino acids were obtained from Chem-Impex International and Nova Biochem. The $\alpha$-carboxyl groups of the incoming amino acids were activated with 1-hydroxy-7-azabenzotriazole (HOAt, Applied Biosystems), the Fmoc protecting group on the last amino acid added was removed with $20 \%$ piperidine in N,Ndimethyl formamide, and the activated $\alpha$-carboxyl group and the deprotected amino group were coupled by reaction for one hour. The N-terminal amino group was acetylated with acetic anhydride. Side chain functional groups were deprotected and the peptide cleaved from the resin by reaction with a cleavage cocktail composed of $88 \%$ trifluoroacetic acid (TFA), $5.8 \%$ phenol, $2 \%$ triisopropylsilane and $4.2 \%$ water for 4 hours. The cleaved and deprotected peptide mixture was lyophilized, redissolved in water, and the peptide was isolated by reverse-phase 
HPLC on a semi-prep scale C18 column. The peak corresponding to the desired peptide in the chromatogram was identified by MALDI-TOF mass spectrometry.

\section{NMR Measurements}

NMR spectra were measured on a Varian Inova $500 \mathrm{MHz}$ spectrometer equipped with waveform generators, a Performa $\mathrm{X}, \mathrm{Y}, \mathrm{Z}$ gradient module, and a ${ }^{1} \mathrm{H}\left\{{ }^{13} \mathrm{C},{ }^{15} \mathrm{~N}\right\}$ tripleresonance, $\mathrm{X}, \mathrm{Y}, \mathrm{Z}$ triple-axis pulsed field gradient probe. One-dimensional ${ }^{1} \mathrm{H}$ NMR spectra and two-dimensional TOCSY, ROESY and NOESY and BASHD (band-selective homonuclear decoupled)-TOCSY, ROESY AND NOESY spectra (30-35) were measured by standard pulse sequences with suppression of the water resonance by presaturation. BASHD experiments were run with band selection of both the $\mathrm{NH}$ and $\mathrm{C}_{\alpha} \mathrm{H}$ regions (33-35).

NMR samples were prepared in $90 \% \mathrm{H}_{2} \mathrm{O} / 10 \% \mathrm{D}_{2} \mathrm{O}$. The peptide concentration was generally $5 \mathrm{mM}$ and the heparin concentration $20 \mathrm{mM}$ in terms of the sulfated uronic acid-( $1 \rightarrow 4)$ glucosamine repeating disaccharide unit. TMSP was added as the chemical shift reference. Shigemi tubes were used for all NMR experiments; the sample volume was $300 \mu \mathrm{L}$.

\section{Circular Dichroism Measurements}

$\mathrm{CD}$ spectra were measured for $\mathrm{pH} 5.5$ solutions of heparin, the peptide, and heparin plus peptide with a Jasco J-600 spectrophotometer. Peptide solutions were $0.1 \mathrm{mM}$, the heparin solution was $0.4 \mathrm{mM}$ (in terms of the concentration of the major repeating disaccharide unit) and heparin plus peptide solutions were $0.1 \mathrm{mM}$ peptide and $0.4 \mathrm{mM}$ heparin.

\section{Isothermal Titration Calorimetry}

ITC experiments were performed at $25^{\circ} \mathrm{C}$ using a MicroCal VP-ITC MicroCalorimeter (36, 37). Heparin and peptide solutions were prepared in $50 \mathrm{mM} \mathrm{pH} 7.0$ phosphate buffer at different concentrations of $\mathrm{NaCl}$. The heparin solutions ranged in concentration from $0.68 \mathrm{mM}$ to 0.092 $\mathrm{mM}$, in terms of an average molecular weight of $12,000 \mathrm{D}$, and the peptide solutions ranged from $0.15 \mathrm{mM}$ to $0.18 \mathrm{mM}$. The peptide solution was placed in the calorimeter cell and the heparin solution was loaded into the syringe injector. The titrations involved the injection of $5 \mu \mathrm{L}$ of heparin solution into the peptide solution, with a $250 \mathrm{sec}$ delay between injections. The ITC unit measured the heat absorbed due to interaction of heparin with peptide following the addition of each aliquot of heparin. Calorimetric titration data were fit to give the stoichiometry $(\mathrm{N})$, association constant $(\mathrm{K})$, and binding enthalpy $(\Delta \mathrm{H})$, using the Origin 5.0 non-linear least squares program supplied with the Microcal VP-ITC instrument. The reported binding constants are the average of duplicate measurements. The effect of dilution of the heparin solution in the titration cell was removed by subtracting calorimetric data for a blank titration, which consisted of titration of heparin into buffer solution.

\section{Affinity Chromatography}

Affinity chromatography experiments were performed with a Dionex 500 HPLC system using a HiTrap heparin HP column $(0.7 \mathrm{~cm} \times 2.5 \mathrm{~cm}, 1.0 \mathrm{~mL}$ column volume $)$. Peptide solutions were prepared in $5 \mathrm{mM} \mathrm{pH} 7.0$ phosphate buffer and were eluted using a linear gradient of low salt and high salt buffers $(5 \mathrm{mM} \mathrm{pH} 7.0$ phosphate and $5 \mathrm{mM} \mathrm{pH} 7.0$ phosphate plus $1.0 \mathrm{M}$ $\mathrm{NaCl}$, respectively) at a flow rate of $0.6 \mathrm{~mL} / \mathrm{min}$ with a 65 -min. gradient reaching $65 \%$ high salt buffer. 


\section{RESULTS}

\section{Neutralization of the Anticoagulant Activity of Heparin}

The effect of L-HIPAP and D-HIPAP on the anticoagulant activity of heparin was determined using the Coatest Heparin method. The absorbance of pNA for the standard heparin solutions decreased linearly as the heparin concentration increased, confirming that the FXa activity is proportional to the amount of pNA formed. The results in Figure 1, presented in terms of the $\%$ FXa activity, indicate that both L-HIPAP and D-HIPAP restore FXa activity in a concentration-dependent manner and, most importantly, that they are equally effective in restoring activity. In view of these findings, we have characterized in detail the interaction of L-HIPAP and D-HIPAP with heparin by ${ }^{1} \mathrm{H}$ NMR and isothermal titration calorimetry and heparin affinity chromatography.

\section{${ }^{1} \mathrm{H}$ NMR Studies of the Interaction of L-HIPAP and D-HIPAP with Heparin}

To determine the appropriate conditions for characterization of the interaction of L-HIPAP and D-HIPAP with heparin by NMR, spectra were measured at heparin-to-peptide ratios ranging from 0:1 to 5:1, where the heparin concentration is expressed in terms of the repeating heparin disaccharide unit. The spectrum was measured for a $5 \mathrm{mM}$ solution of L-HIPAP at $\mathrm{pH} 5.1$. Heparin was then added directly to the NMR tube to increase the ratio in increments of 0.5:1, the $\mathrm{pH}$ adjusted to between 5.0 and 6.0, and the spectrum measured again until a ratio of 5:1 was reached. At a ratio of $0.5: 1$, the solution was cloudy. At this ratio, essentially all the heparin is bound to peptide (as indicated by the ITC results that follow), while peptide exists both free and bound to heparin. The backbone amide NH region of the NMR spectrum shows most of the features seen before the addition of heparin, but the resonances are broadened. At a ratio of 1:1, more peptide is bound and there is extensive broadening of the resonances. At a ratio of 2:1, the solution was clear and the resonances sharper. The spectrum changed little and the solution remained clear as the ratio was increased to $4: 1$. Above a ratio of $4: 1$, there was no further change in the spectrum, indicating that essentially all the peptide was in a bound form. The resonances of heparin-bound peptide are broader than those of the free peptide, presumably because the bound peptide has the motional properties of heparin and thus its resonances have shorter relaxation times.

The backbone amide $\mathrm{NH}$ resonances of free and heparin-complexed peptides were assigned to amino acid type using scalar connectivities to side chain protons in BASHD-TOCSY spectra. Then the resonances were assigned to specific amino acids in the peptide sequence using dipolar cross peaks in the $\mathrm{C}_{\alpha} \mathrm{H}-\mathrm{NH}$ region of BASHD-ROESY spectra for the free peptides or BASHDNOESY spectra for the heparin-complexed peptides (33-35). Because of the multiple lysines and alanines in the peptides, there is extensive overlap of cross peaks in their two-dimensional TOCSY, ROESY and NOESY spectra. With the increased resolution in two-dimensional BASHD-TOCSY, ROESY and NOESY spectra, it was possible to completely assign their ${ }^{1} \mathrm{H}$ NMR spectra; resolution is increased in the BASHD spectra as a result of collapse of ${ }^{1} \mathrm{H}$-spin coupled multiplets to singlets in the indirectly detected (band selected) F1 dimension. To resolve all of the cross peaks, it was necessary to measure BASHD-TOCSY and BASHDROESY spectra with band selection of the $\mathrm{C}_{\alpha} \mathrm{H}$ and the $\mathrm{NH}$ regions $(34,35)$.

The chemical shifts of resonances for all the protons in each peptide were obtained from BASHD-TOCSY subspectra. The chemical shifts of the backbone amide NH protons of free and heparin-complexed L-HIPAP are presented in Table 1. The chemical shifts of the corresponding protons of D-HIPAP are identical to those reported in Table 1. 


\section{Effect of Heparin on Titration of the Lysine Ammonium Groups}

The interaction of heparin with L-HIPAP and D-HIPAP is expected to involve, in part at least, electrostatic interactions between the lysine ammonium and arginine guanidinium groups of the peptides and anionic sites on heparin. If so, the apparent $\mathrm{pK}_{\mathrm{A}} \mathrm{s}$ of the lysine ammonium groups that interact with heparin will be increased (38). $\mathrm{pK}_{\mathrm{A}}$ values can be determined for each lysine ammonium group in a peptide from the $\mathrm{pH}$ dependence of the chemical shifts of the side chain $\mathrm{C}_{\varepsilon} \mathrm{H}_{2}$ protons (39). Due to broadening of resonances for the heparin-complexed peptides, resonances for the $\mathrm{C}_{\varepsilon} \mathrm{H}_{2}$ protons of each of the six lysines of heparin-complexed L-HIPAP could not be resolved. However, the $\mathrm{C}_{\varepsilon} \mathrm{H}_{2}$ resonances for the six lysines shift together as their ammonium groups are titrated, indicating that all six lysine ammonium groups interact with heparin to some extent. Thus, the effect of binding on titration of the six lysine ammonium groups was established using the chemical shift of the composite $\mathrm{C}_{\varepsilon} \mathrm{H}_{2}$ resonance. Composite chemical shift - $\mathrm{pH}$ data for free L-HIPAP and L-HIPAP plus heparin are presented in Figure $2 \mathrm{~A}$. The titration curve is shifted to higher $\mathrm{pH}$ in the presence of heparin, consistent with interaction of the lysine ammonium groups with heparin.

The resonance for the $\mathrm{C}_{\delta} \mathrm{H}_{2}$ protons of the Arg residue also is shifted in the presence of heparin (Figure 2B), indicating interaction of the guanidinium group of arginine with heparin. At pH 11 , where the lysine ammonium groups are essentially completely titrated to the neutral amino form, the resonance for the $\mathrm{C}_{\delta} \mathrm{H}_{2}$ protons of arginine is still displaced in the presence of heparin indicating that the guanidinium group of arginine still interacts with heparin. At $\mathrm{pH}>11$, the chemical shift of the $\mathrm{C}_{\delta} \mathrm{H}_{2}$ resonance shifts back to that of the free peptide due to the competitive binding of $\mathrm{Na}^{+}$from the added $\mathrm{NaOH}$ to heparin and, starting at $\mathrm{pH} \sim 12$, titration of the guanidinium group.

Resonances for the NH protons also provide evidence for interaction of the lysine ammonium and arginine guanidinium groups with heparin. The lysine ammonium and arginine guanidinium protons of the free peptide give broad resonances at low $\mathrm{pH}$, but disappear due to fast exchange with solvent protons at $\mathrm{pHs}$ of $\sim 4$ and 5, respectively, in spectra measured as a function of increasing $\mathrm{pH}$. These resonances are present in spectra measured at $\mathrm{pHs}>5$ and 6 , respectively, in the presence of heparin, indicating that the ammonium and guanidinium protons are shielded from exchange by interaction of the ammonium and guanidinium groups with heparin.

\section{Conformational Properties of L-HIPAP}

The conformation of L-HIPAP free and complexed by heparin was investigated using the nuclear Overhauser effect (NOE) (40). The free peptide is an ensemble of rapidly interconverting random coil conformations, as indicated by the absence of NOEs characteristic of peptides in a helical or $\beta$-strand secondary structure in 2D ROESY spectra of the free peptide, including cross peaks between amide $\mathrm{NH}$ protons on adjacent residues $(\mathrm{NN}(\mathrm{i}, \mathrm{i}+1))$. Likewise, patterns of NOEs characteristic of helical or $\beta$-strand secondary structures were not observed in 2D NOESY spectra of the heparin-complexed peptide. However sequential NN(i,i+1) NOEs were observed for the $S^{1}-A^{5}$ and $V^{11}-K^{16}$ segments and between $A^{9}$ and $\mathrm{K}^{10}$ of the heparincomplexed peptide, which together with reduced ${ }^{3} \mathrm{~J}_{\mathrm{NH}-\mathrm{C} \alpha \mathrm{H}}$ coupling constants indicate that the heparin-complexed peptide exists in fewer, more highly populated, conformations. However, the NOE data were not sufficient to establish the conformation(s) of the heparin-complexed peptide.

The CD spectra in Figure 3 provide additional information about the conformations of free and heparin complexed L-HIPAP and D-HIPAP. A helical secondary structure for L-HIPAP would show strong negative ellipticities at 208 and $222 \mathrm{~nm}$ and a positive ellipticity near $190 \mathrm{~nm}$ while a beta sheet secondary structure would show a strong negative ellipticity near $215 \mathrm{~nm}$ 
and a positive ellipticity at $195 \mathrm{~nm}$ (41). The CD spectra change in the presence of heparin, but do not show these features, which is consistent with an ensemble of conformations. The CD spectra of L-HIPAP and D-HIPAP are essentially mirror images, the small differences between the CD spectra of the heparin-complexed peptides being due to the CD spectrum of heparin (see Supporting Information).

\section{Heparin-Peptide Binding Constants}

Binding constants for the interaction of L-HIPAP and D-HIPAP with heparin were determined by isothermal titration calorimetry. A typical titration curve for L-HIPAP is shown in Figure 4. Binding constants were obtained by fitting the titration data to a model involving multiple equivalent binding sites. Results are reported in Table 2 for the binding of L-HIPAP by heparin as a function of the $\mathrm{NaCl}$ concentration. Results are also reported in Table 2 for the binding of D-HIPAP by heparin at $\mathrm{NaCl}$ concentrations of 0.0815 and $0.0915 \mathrm{M}$.

\section{Affinity Chromatography}

The peptides L-HIPAP and D-HIPAP were eluted from the heparin affinity column with essentially identical retention times (44.54 min. and 44.38 min., respectively).

\section{DISCUSSION}

Both L-HIPAP and D-HIPAP restore the activity of FXa. Because L-amino acid peptides are degraded by enzyme-catalyzed proteolysis, the finding that L-HIPAP and D-HIPAP are equally effective is particularly significant. Restoration of the activity of FXa by the parent HIP peptide was also assayed by the Coatest Heparin method (25). However a direct quantitative comparison of the efficacy of the parent HIP peptide and the two HIP peptide analogs is not possible because different heparin preparations were used in the two studies.

The results in Figure 2 indicate that the lysine ammonium groups of the HIPAP peptides are involved in binding, as expected if binding includes electrostatic interactions between cationic sites on the peptides and anionic sites on heparin. That the $\mathrm{C}_{\mathrm{e}} \mathrm{H}_{2}$ resonances for all six lysines shift together in the chemical shift-pH titration experiment indicates that all six lysine ammonium groups are involved in the interaction with heparin. The differences between the chemical shifts of the backbone amide NH protons of free and heparin-complexed L-HIPAP (Table 1) are plotted in Figure 5. The difference is largest for the lysines and arginine, consistent with their interaction with heparin.

The finding that L-HIPAP and D-HIPAP are equally effective as agents for neutralization of the anticoagulant activity of heparin and that their heparin binding constants are identical suggests that it is the pattern, or spatial arrangement, of the lysine and arginine residues in LHIPAP and D-HIPAP that is important in their interaction with heparin and not the recognition of a complementary structure by heparin. This conclusion is consistent with reports that HIP peptide binds heparin by non-specific charge interactions and that a peptide with a scrambled HIP peptide sequence (CKDKTPRAKQAAAKK) had no effect on FXa activity when assayed by the Coatest Heparin method $(26,42)$. The finding that the spatial arrangement of the six lysines and the one arginine is critical and that D-HIPAP is as effective as L-HIPAP should aid in the design of other HIP analog peptides as potential therapeutic agents for neutralization of the anticoagulant activity of heparin.

The binding constants in Table 2 also provide information about the nature of the interaction of L-HIPAP and D-HIPAP with heparin. Heparin is a highly negatively charged polyelectrolyte, with a fraction of its negative charge neutralized by bound counterions (43). The counterion condensation model of polyelectrolyte binding developed by Manning (44, 
45) predicts that the fraction of a $\mathrm{Na}^{+}$ion condensed per anionic charge on heparin $(\theta)$ is 0.59 (43). Experimental values of 0.58 and 0.63 have been reported $(46,47)$. Counterions are released when heparin binds to peptide, as described by the following binding equilibrium for sodium heparinate $(38,43,48)$ :

$$
\text { Peptide }+\mathrm{Hep}\left(\mathrm{Na}^{+}\right)_{\mathrm{x}} \leftrightarrow \text { Peptide }-\mathrm{Hep}\left(\mathrm{Na}^{+}\right)_{\mathrm{x}-\mathrm{n}}+\mathrm{nNa}^{+}
$$

The number of $\mathrm{Na}^{+}$ions displaced by peptide, $\mathrm{n}$, is equal to $\mathrm{Z} \psi$, where $\mathrm{Z}$ represents the number of ionic interactions the peptide makes with heparin and $\psi$ is the apparent fraction of a $\mathrm{Na}^{+}$ condensed per heparin anionic charge. $\psi$ includes both the fraction of a $\mathrm{Na}^{+}$ion condensed per heparin anionic charge $(\theta)$ and the screening effect of condensed $\mathrm{Na}^{+}$ions on the interactions of residual heparin anionic charges. Thus, $\psi$ is larger than $\theta ; \psi=0.8$ has been reported for heparin (49).

Equation 5 predicts the extent of peptide binding will decrease as the $\mathrm{Na}^{+}$concentration is increased, as found for the binding of L-HIPAP (Table 2). The dependence of the binding constant on the $\mathrm{Na}^{+}$concentration is given by the equation $(48,50,51)$ :

$$
\log K_{b}=\log K_{\text {nonionic }}-Z \psi \log [\mathrm{Na}+]
$$

where $K_{b}$ is the measured binding constant and $K_{\text {nonionic }}$ the contribution of nonionic interactions to the binding constant. A plot of $\log K_{b}$ vs $\log \left[\mathrm{Na}^{+}\right]$is linear, with a slope of -2.35 and an intercept of 2.12 (see Supporting Information).

The slope indicates that, on average, $2.35 \mathrm{Na}^{+}$ions are displaced per peptide interaction. Using the value of 0.8 for $\psi$, a value of 2.94 is obtained for Z, i.e. L-HIPAP makes on average $\sim 3$ ionic interactions with heparin that result in the displacement of 2.34 bound $\mathrm{Na}^{+}$ions.

The binding constant is strongly dependent on the concentration of $\mathrm{Na}^{+}$, decreasing from 5.3 $\times 10^{4}$ to $5.0 \times 10^{3}$ as the concentration of $\mathrm{Na}^{+}$is increased from $0.082 \mathrm{M}$ to $0.232 \mathrm{M}$ (Table 2). Both nonionic and ionic interactions contribute to the binding:

$$
K_{b}=K_{\text {nonionic }} K_{\text {ionic }}
$$

The intercept of 2.12 gives a value of 131 for $K_{\text {nonionic }}$. Using this value, $K_{\text {ionic }}$ is calculated to be 400 at a $\mathrm{Na}^{+}$concentration of $0.082 \mathrm{M}$ and 38 at a Na${ }^{+}$concentration of $0.232 \mathrm{M}$. $K_{\text {nonionic }}$ and $K_{\text {ionic }}$ contribute equally to $K_{b}$ at a $\mathrm{Na}^{+}$concentration of $0.016 \mathrm{M}$. The relative magnitudes of $K_{\text {nonionic }}$ and $K_{\text {ionic }}$ indicate that both ionic and nonionic interactions, e.g. hydrogen bonding or hydrophobic interactions, make a significant contribution to the binding constant for the interaction of L-HIPAP with heparin. The relatively large displacement of the chemical shift of the glutamine NH resonance (Figure 5) suggests that hydrogen bonding to the side chain amide group of the glutamine residue is involved in binding to heparin.

The binding constants for L-HIPAP and D-HIPAP are identical at $\mathrm{Na}^{+}$concentrations of 0.0815 and $0.0915 \mathrm{M}$ (Table 2), and their elution times from the heparin affinity column are the same, both of which are consistent with the finding that L-HIPAP and D-HIPAP are equally effective at neutralizing the anticoagulant activity of heparin.

The average value of $\mathrm{N}$, the number of peptides bound per heparin molecule, is 6.9 (Table 2), which corresponds to the binding of one peptide molecule per hexasaccharide segment of heparin. The thermodynamic parameters in Table 2 indicate that the binding reaction is entropically driven mainly by the release of $\sim 3 \mathrm{Na}^{+}$ions per peptide bound. However, other interactions also contribute to the overall thermodynamics of the binding, including both ionic and non-ionic interactions (enthalpic) and peptide conformational changes (entropic). 


\section{Summary}

The coagulation assay results indicate that L-HIPAP and D-HIPAP are equally effective agents for neutralization of the anticoagulant activity of heparin. NMR chemical shift data suggest that the two peptides interact identically with heparin and their binding constants, as determined by ITC, and their heparin affinity chromatography elution times are the same. The HIPAP peptides bind to heparin by a combination of ionic and nonionic interactions, with the ionic contribution decreasing as the $\mathrm{Na}^{+}$counterion concentration increases. These results, taken together, suggest that $\mathrm{D}$-amino acid peptides show promise as proteolytically stable therapeutic agents for neutralization of the anticoagulant activity of heparin.

\section{Supplementary Material}

Refer to Web version on PubMed Central for supplementary material.

\section{Acknowledgements}

The authors thank one of the reviewers for discussion of the thermodynamics of the binding interactions.

\section{References}

1. Rodén, L. Highlights in the History of Heparin. In: Lane, DA.; Lindahl, U., editors. Heparin: Chemical and Biological Properties, Clinical Applications. CRC Press, Inc.; Boca Raton, FL: 1989. p. 1-23.

2. Rabenstein DL. Heparin and heparin sulfate: structure and function. Nat. Prod. Rep 2002;19:312-331. [PubMed: 12137280]

3. Olivercrona, T.; Bengtsson-Olivercrona, G. Heparin and Lipases. In: Lane, DA.; Lindahl, U., editors. Heparin: Chemical and Biological Properties, Clinical Applications. CRC Press, Inc.; Boca Raton, FL: 1989. p. 335-361.

4. Liu G, Hultin M, Østergaard P, Olivecrona T. Interaction of size-fractionated heparins with lipoprotein lipase and hepatic lipase in the rat. Biochem. J 1992;285:731-736. [PubMed: 1497611]

5. Yu H, Muñoz EM, Edens RE, Linhardt RJ. Kinetic studies on the interactions of heparin and complement proteins using surface plasmon resonance. Biochim. Biophys. Acta 2005;1726:168-176. [PubMed: 16125850]

6. Folkman J, Langer R, Linhardt RJ, Haudenschild C, Taylor S. Angiogenesis inhibition and tumor regression caused by heparin or a heparin fragment in the presence of cortisone. Science 1983;221:719-725. [PubMed: 6192498]

7. Vlodavsky I, Abboud-Jarrous G, Elkin M, Naggi A, Casu B, Sasisekharan R, Ilan N. The impact of heparanase and heparin on cancer metastasis and angiogenesis. Pathophysiology of Haemostasis and Thrombosis 2006;35:116-127. [PubMed: 16855356]

8. Sasisekharan R, Shriver Z, Venkataraman G, Narayanasami U. Roles of heparan-sulfate glycosaminoglycans in cancer. Nat. Rev. Cancer 2002;2:521-528. [PubMed: 12094238]

9. Berry D, Lynn DM, Berry E, Sasisekharan R, Langer R. Heparin localization and fine structure regulate Burkitt's lympnoma growth. Biochem. Biophys. Res. Commun 2006;348:850-856. [PubMed: 16904641]

10. Ludwig RJ, Alben S, Boehncke W. Structural Requirements of heparin and related molecules to exert a multitude of anti-inflammatory activities. Mini-Rev. Med. Chem 2006;6:1009-1023. [PubMed: 17018000]

11. Lin Y-L, Lei H-Y, Lin Y-S, Yeh T-M, Chen S-H, Liu H-S. Heparin inhibits dengue-2 virus infection of five human liver cell lines. Antiviral Res 2002;56:93-96. [PubMed: 12323403]

12. Holodniy M, Kim S, Katzenstein D, Konrad M, Groves ET, Merigan TC. Inhibition of human immunodeficiency virus gene amplification by heparin. J. Clin. Microbiol 1991;29:676-679. [PubMed: 1909709] 
13. Herold BC, Gerber SI, Polonsky T, Belval BJ, Shaklee PN, Holme K. Identification of structural features of heparin required for inhibition of herpes simplex virus type 1 binding. Virology 1995;206:1108-1116. [PubMed: 7856085]

14. Howell AL, Taylor TH, Miller JD, Groveman DS, Eccles EH, Zacharski LR. Inhibition of HIV-1 infectivity by low molecular weight heparin. Results of in vitro studies and a pilot clinical trial in patients with advanced Aids. Int. J. Clin. Lab. Res 1996;26:124-131. [PubMed: 8856366]

15. Clayette P, Moczar E, Mabondzo A, Martin M, Toutain B, Marce D, Dormont D. Inhibition of human immunodeficiency virus infection by heparin derivatives. Aids Res. Human Retrov 1996;12:63-69.

16. Conrad, HE. Heparin-Binding Proteins. Academic Press; New York: 1998.

17. Capila I, Linhardt RJ. Heparin-protein interactions. Angew. Chem. Int. Ed 2002;41:390-412.

18. Mulloy B, Linhardt RJ. Order out of complexity - protein structures that interact with heparin. Curr. Opin. Struct. Biol 2001;11:623-628. [PubMed: 11785765]

19. Jin L, Abrahams JP, Skinner R, Petitou M, Pike RN, Carrell RW. The anticoagulant activation of antithrombin by heparin. Proc. Natl. Acad. Sci. U.S.A 1997;94:14683-14688. [PubMed: 9405673]

20. Freitas CF, Faro R, Dragosavac D, Clozel M, De Nucci G, Antunes E. Role of endothelin-1 and thromboxane $\mathrm{A} 2$ in the pulmonary hypertension induced by heparin-protamine interaction in anesthetized dogs. J. Cardiovasc. Pharm 2004;43:106-112.

21. Chang LC, Lee HF, Yang Z, Yang VC. Low molecular weight protamine (LMWP) as a nontoxic heparin/low molecular weight heparin antidote(I): preparation and characterization. AAPS Pharmsci. (electronic resource) 2001;3:E17.

22. Liang JF, Yang VC, Vaynshteyn Y. The minimal functional sequence of protamine. Biochem. Biophys. Res. Commun 2005;336:653-659. [PubMed: 16139792]

23. Montalescot G, Fischman AJ, Strauss HW, Wilkinson RA, Ahmad M, Fitzgibbon C, Robinson DW, Zapol WM. Imaging the ovine heparin-protamine interaction with 111In-protamine. J. Appl. Physiol 1993;75:963-971. [PubMed: 8226502]

24. Schick BP, Maslow D, Moshinski A, San Antonio JD. Novel concatameric heparin-binding peptides reverse heparin and low-molecular-weight heparin anticoagulant activities in patient plasma in vitro and in rats in vivo. Blood 2004;103:1356-1363. [PubMed: 14576044]

25. Rohde LH, Julian J, Babaknia A, Carson DD. Cell surface expression of HIP, a novel heparin/heparan sulfate-binding protein, of human uterine epithelial cells and cell lines. J. Biol. Chem 1996;271:11824-11830. [PubMed: 8662617]

26. Liu S, Zhou F, Höök M, Carson DD. A heparin-binding synthetic peptide of heparin/heparan sulfateinteracting protein modulates blood coagulation activities. Proc. Natl. Acad. Sci. U.S.A 1997;94:1739-1744. [PubMed: 9050848]

27. Liu S, Smith SE, Julian J, Rohde LH, Karin NJ, Carson DD. cDNA cloning and expression of HIP, a novel cell surface heparan sulfate/heparin-binding protein of human uterine epithelial cells and cell lines. J. Biol. Chem 1996;271:11817-11823. [PubMed: 8662616]

28. Liu S, Julian J, Carson DD. A peptide sequence of heparin/heparan sulfate (HP/HS)-interacting protein supports selective, high affinity binding of HP/HS and cell attachment. J. Biol. Chem 1998;273:97189726. [PubMed: 9545307]

29. Carpino LA, Han GY. 9-Fluorenylmethoxycarbonyl amino-protecting group. J. Org. Chem 1972;37:3404-3409.

30. Braunschweiler L, Ernst R. Coherence transfer by isotropic mixing: application to proton correlation spectroscopy. J. Magn. Reson 1983;53:521-528.

31. Bothner-By A, Stephens R, Lee J, Warren C, Jeanloz R. Structure determination of a tetrasaccharide: transient nuclear Overhauser effects in the rotating frame. J. Am. Chem. Soc 1984;106:811-813.

32. Neuhaus, D.; Williamson, M. The Nuclear Overhauser Effect in Structural and Conformational Analysis. VCH; Weinheim: 1989. p. 253-305.

33. Krishnamurthy VV. Application of semi-selective excitation sculpting for homonuclear decoupling during evolution in multi-dimensional NMR. Magn. Reson. Chem 1997;35:9-12.

34. Kaerner A, Rabenstein DL. An $\omega 1$-band-selective, $\omega 1$-homonuclear decoupled ROESY experiment: application to the assignment of 1H NMR spectra of difficult-to-assign peptide sequences. Magn. Reson. Chem 1998;36:601-607. 
35. Wang J, Borchardt D, Rabenstein DL. Improved resolution in two-dimensional ${ }^{1} \mathrm{H}$ NMR spectra of peptides by band-selective, homonuclear decoupling during both the evolution and acquisition periods: application to characterization of the binding of peptides by heparin. Magn. Reson. Chem 2006;44:744-752. [PubMed: 16705624]

36. Wiseman T, Williston S, Brandts JF, Lin L-N. Rapid measurement of binding constants and heats of binding using a new titration calorimeter. Anal. Biochem 1989;179:131-137. [PubMed: 2757186]

37. Freire E, Mayorga O, Straume M. Isothermal titration. Anal. Chem 1990;62:950A-959A.

38. Hari SP, McAllister H, Chuang W-L, Christ MD, Rabenstein DL. Interaction of heparin with a synthetic pentadecapeptide from the $\mathrm{C}$-terminal heparin-binding domain of fibronectin. Biochemistry 2000;39:3763-3773. [PubMed: 10736176]

39. Rabenstein DL, Hari SP, Kaerner A. Determination of acid dissociation constants of peptide sidechain functional groups by two-dimensional NMR. Anal. Chem 1997;69:4310-4316. [PubMed: 9360489]

40. Dyson HJ, Wright PE. Peptide conformation and protein folding. Curr. Opin. Struct. Biol 1993;3:6065.

41. Adler AJ, Greenfield NJ, Fasman GD. Circular dichroism and optical rotatory dispersion of proteins and polypeptides. Methods Enzymol 1973;27:675-735. [PubMed: 4797940]

42. Hoke DE, Carson DD, Höök M. A heparin binding synthetic peptide from human HIP/RPL29 fails to specifically differentiate between anticoagulantly active and inactive species of heparin. J. Neg. Results in Biomed 2003;2:1-10.

43. Rabenstein DL, Robert JM, Peng J. Multinuclear magnetic resonance studies of the interaction of inorganic cations with heparin. Carbohyd. Res 1995;278:239-256.

44. Manning GS. Counterion binding in polyelectrolyte theory. Acc. Chem. Res 1979;12:443-449.

45. Manning GS. The molecular theory of polyelectrolyte solutions with applications to the electrostatic properties of polynucleotides. Q. Rev. Biophys 1978;11:179-246. [PubMed: 353876]

46. Jordan RE, Favreau LV, Braswell EH, Rosenberg RD. Heparin with two binding sites for antithrombin or platelet factor 4. J. Biol. Chem 1982;257:400-406. [PubMed: 7053378]

47. Ascoli F, Botre C, Liquori AM. On the polyelectrolyte behavior of heparin. 1. Binding of sodium ions. J. Phys. Chem 1961;65:1991-1992.

48. Hileman RE, Jennings RN, Linhardt RJ. Thermodynamic analysis of the heparin interaction with a basic cyclic peptide using isothermal titration calorimetry. Biochemistry 1998;37:15231-15237. [PubMed: 9790687]

49. Olson ST, Halvorson HR, Bjork I. Quantitative characterization of the thrombin-heparin interaction. Discrimination between specific and nonspecific binding models. J. Biol. Chem 1991;266:63426352. [PubMed: 2007587]

50. Rabenstein DL, Bratt P, Peng J. Quantitative characterization of the binding of histamine by heparin. Biochemistry 1998;37:14121-14127. [PubMed: 9760248]

51. Record TM Jr. Anderson CF, Lohman TM. Thermodynamic analysis of ion effects on the binding and conformational equilibria of proteins and nucleic acids: the roles of ion association or release, screening, and ion effects on water activity. Q. Rev. Biophys 1978;11:103-178. [PubMed: 353875] 


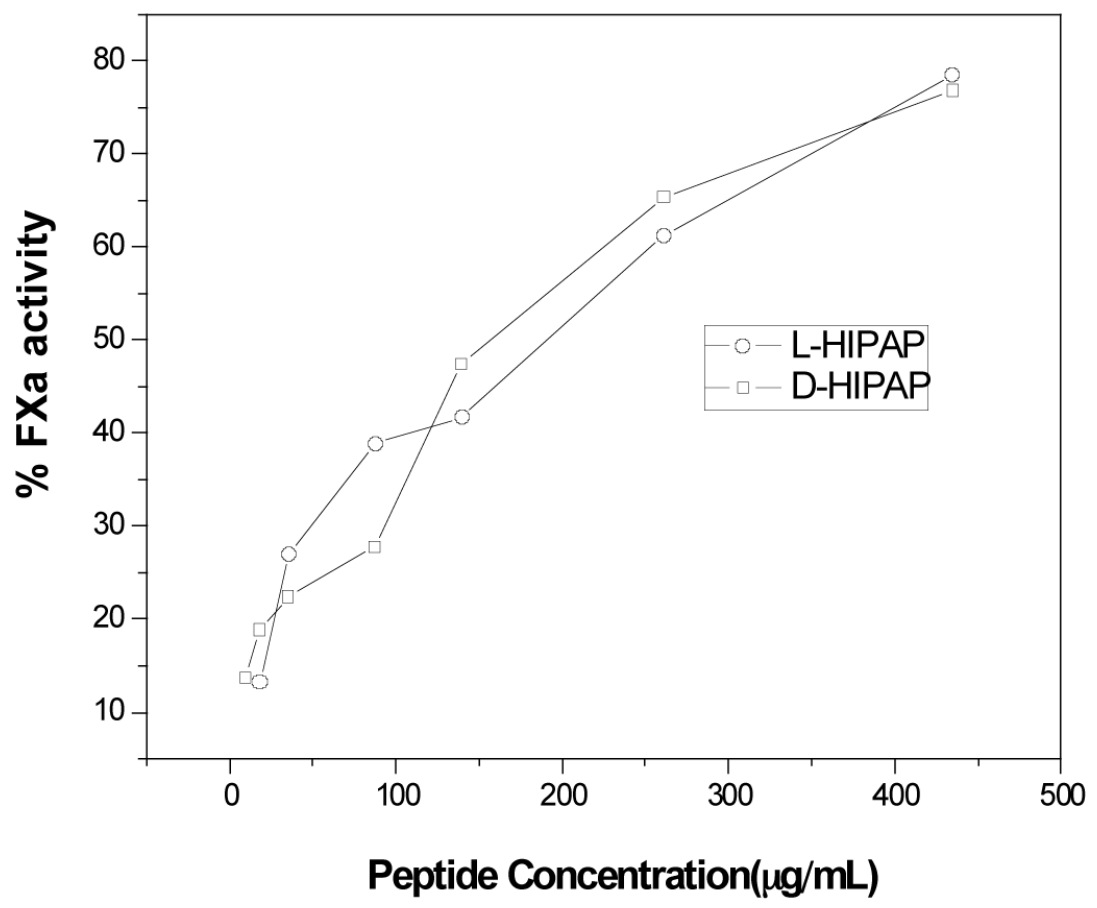

Figure 1.

Restoration of the activity of FXa as a function of the concentration of L-HIPAP and D-HIPAP. 


\section{A}

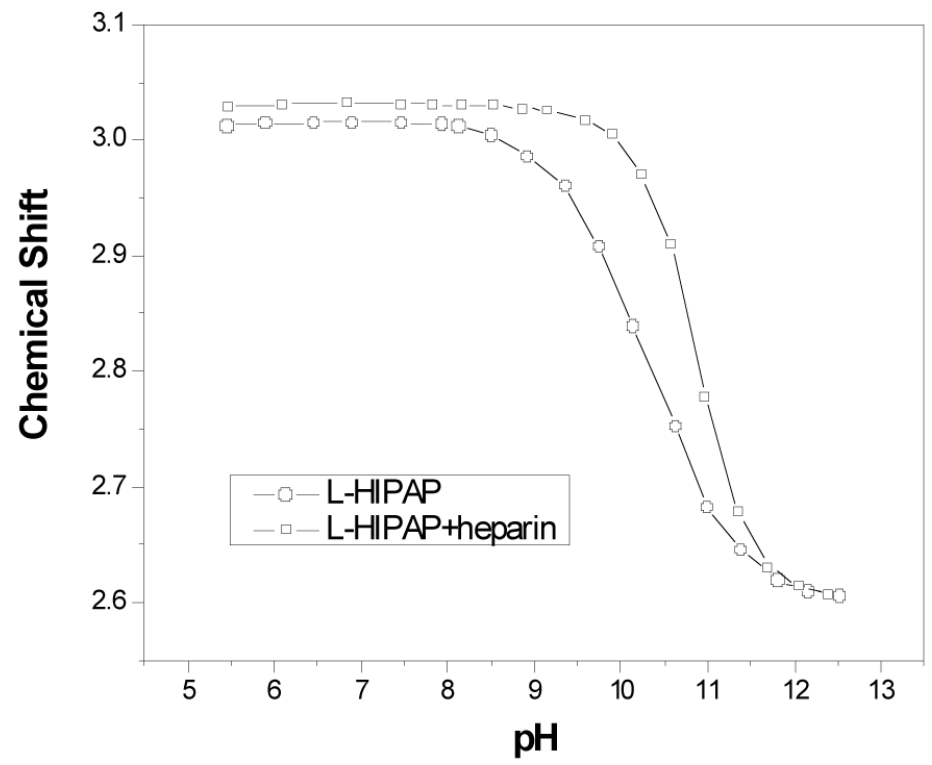

B

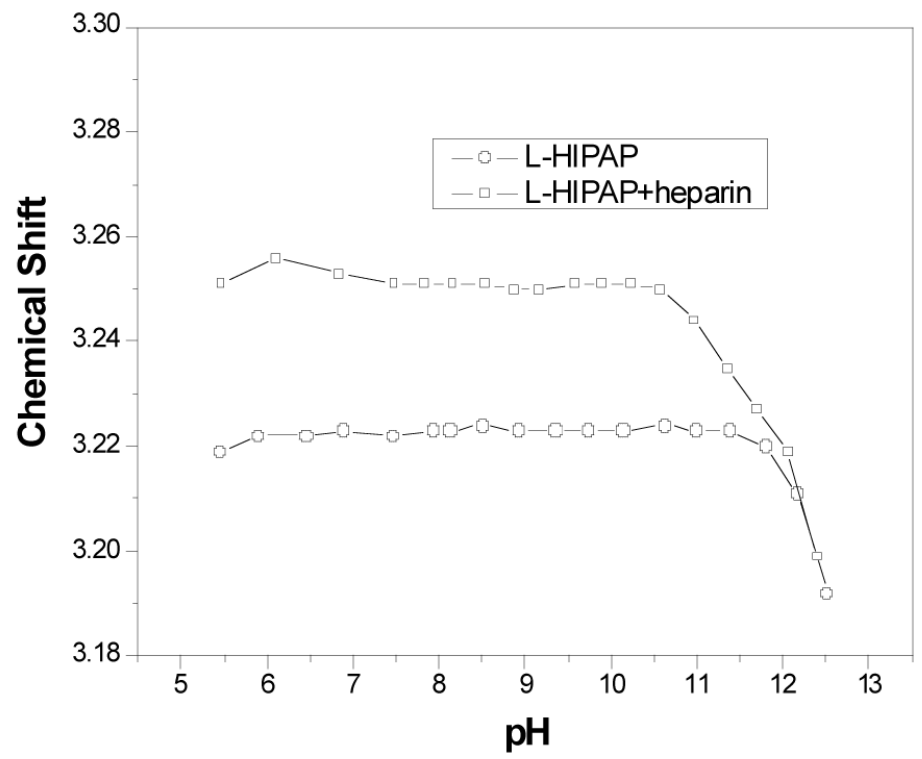

Figure 2.

(A) Composite chemical shift-pH titration curves for the lysine $\mathrm{C}_{\varepsilon} \mathrm{H}_{2}$ protons and (B) chemical shift-pH data for the arginine $\mathrm{C}_{\delta} \mathrm{H}_{2}$ protons of L-HIPAP in the absence and presence of heparin. The open circles are for free peptide, and the open squares are for peptide plus heparin, both at $25^{\circ} \mathrm{C}$. The peptide concentration was $5 \mathrm{mM}$ and the heparin disaccharide-to-peptide ratio was $4: 1$. 


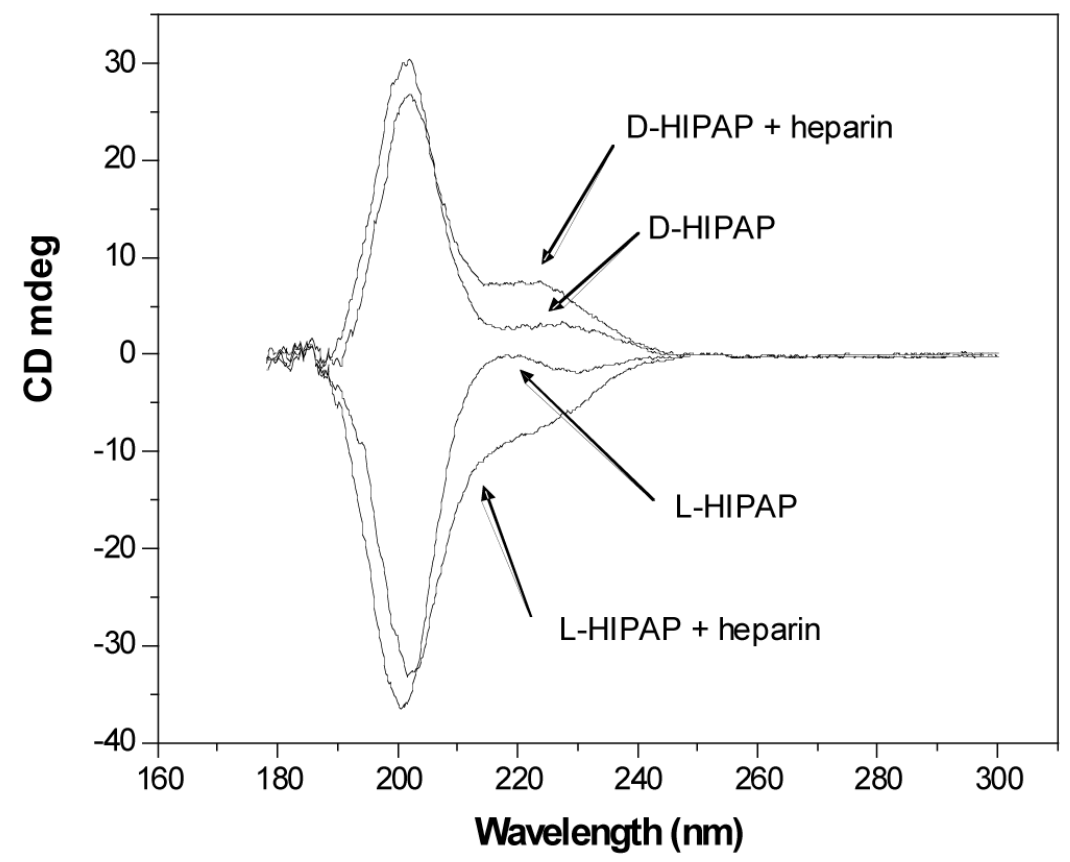

Figure 3.

CD spectra of L-HIPAP and D-HIPAP, free and bound by heparin. 


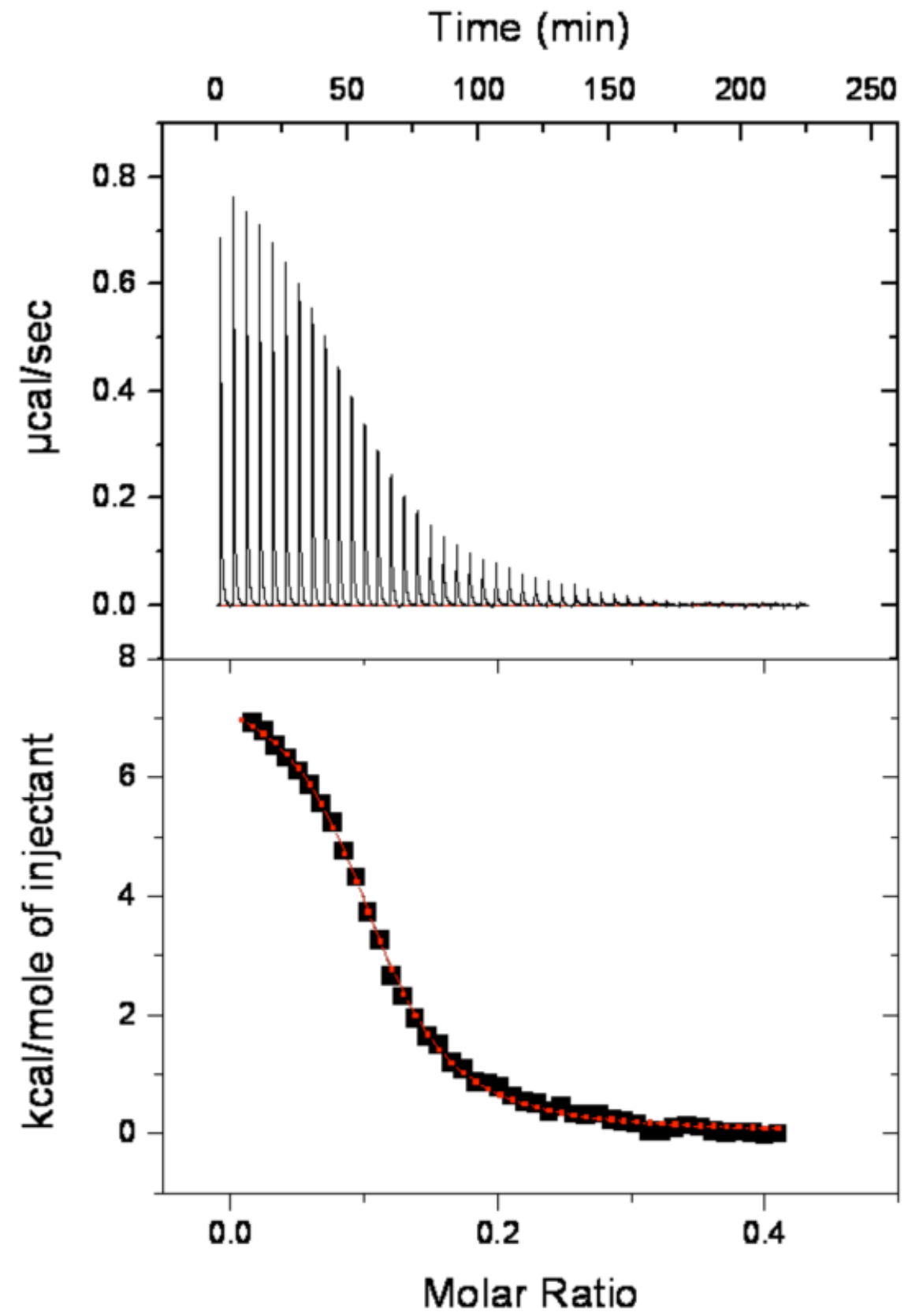

Figure 4.

Binding isotherm for the interaction of L-HIPAP with heparin. The peptide $(0.18 \mathrm{mM}$ in the cell) was titrated with $0.57 \mathrm{mM}$ heparin (in the syringe). In the top figure, the peaks indicate the heat absorbed after each addition of heparin. The peaks were integrated and the total heat per injection (peak area) is plotted as a function of molar ratio in the bottom figure. The line through the points represents the fit of the ITC data that gave the thermodynamic parameters reported in Table 2 . 


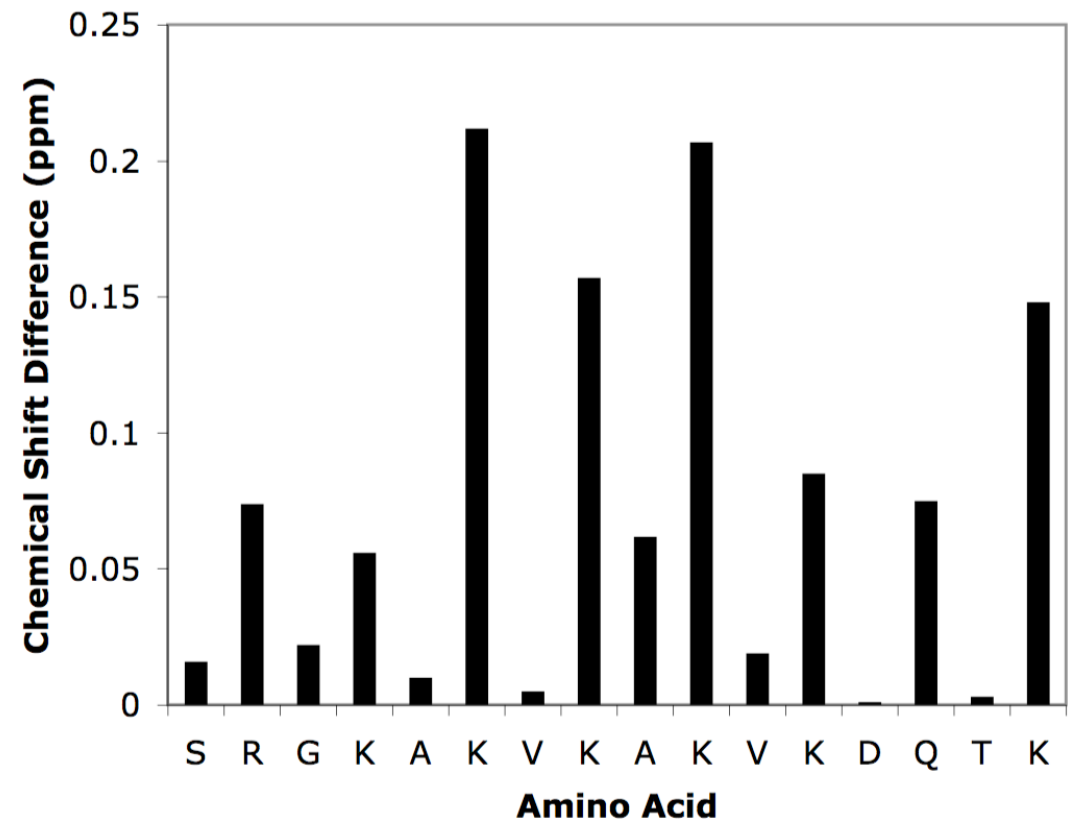

Figure 5.

The change in chemical shift of the backbone amide NH resonances of L-HIPAP upon binding to heparin. Chemical shift difference $=\delta_{\text {free peptide }}-\delta_{\text {with heparin }}$ 
Table 1

Chemical shifts of the backbone amide NH resonances of L-HIPAP and the heparin complex of L-HIPAP

\begin{tabular}{|c|c|c|c|}
\hline Residue & Free Peptide & With Heparin & $\boldsymbol{\delta} \Delta$ \\
\hline $\begin{array}{l}\text { Ser }^{1} \\
\text { Arg }^{2} \\
\text { Gly }^{3} \\
\text { Lys }^{4} \\
\text { Ala }^{5} \\
\text { Lys }^{6} \\
\text { Val }^{7} \\
\text { Lys }^{8} \\
\text { Ala }^{9} \\
\text { Lys }^{10} \\
\text { Val }^{11} \\
\text { Lys }^{12} \\
\text { Asp }^{13} \\
\text { Gln }^{14} \\
\text { Thr }^{15} \\
\text { Lys }^{16}\end{array}$ & $\begin{array}{l}8.352 \\
8.512 \\
8.398 \\
8.164 \\
8.278 \\
8.366 \\
8.137 \\
8.443 \\
8.310 \\
8.391 \\
8.176 \\
8.434 \\
8.345 \\
8.542 \\
8.330 \\
8.256\end{array}$ & $\begin{array}{l}8.336 \\
8.438 \\
8.376 \\
8.108 \\
8.268 \\
8.154 \\
8.132 \\
8.286 \\
8.248 \\
8.184 \\
8.157 \\
8.349 \\
8.346 \\
8.467 \\
8.327 \\
8.108\end{array}$ & $\begin{array}{c}0.016 \\
0.074 \\
0.022 \\
0.056 \\
0.010 \\
0.212 \\
0.005 \\
0.157 \\
0.062 \\
0.207 \\
0.019 \\
0.085 \\
-0.001 \\
0.075 \\
0.003 \\
0.148\end{array}$ \\
\hline
\end{tabular}

${ }^{a} \Delta \delta=\delta$ free peptide $-\delta_{\text {with heparin }}$ 


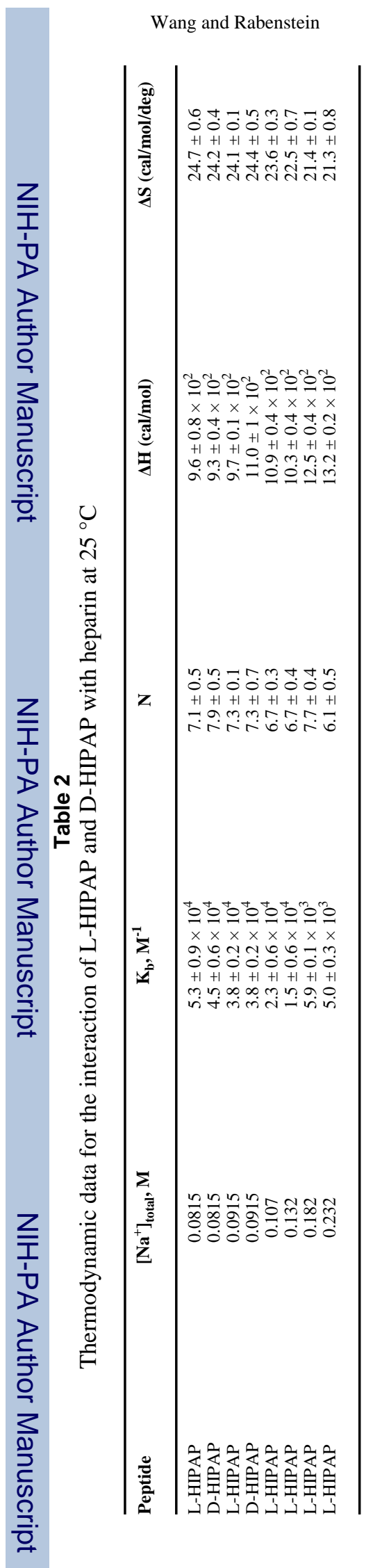

Biochemistry. Author manuscript; available in PMC 2008 September 2. 